\title{
MULTIVARIATE IMPACT ANALYSIS OF PARTHENIUM HYSTEROPHORUS INVASION ON ABOVE-GROUND PLANT DIVERSITY IN POTHWAR REGION OF PAKISTAN
}

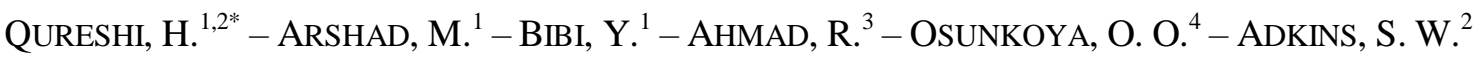 \\ ${ }^{1}$ Department of Botany, PMAS-Arid Agriculture University, 46300-Rawalpindi, Pakistan \\ ${ }^{2}$ School of Agriculture and Food Science, The University of Queensland \\ St. Lucia-4072 Brisbane, Australia \\ ${ }^{3}$ Quality Enhancement Cell, PMAS-Arid Agriculture University- 46300 Rawalpindi, Pakistan \\ ${ }^{4}$ Invasive Plant \& Animal Science, Biosecurity Unit, Queensland-Department of Agriculture \& \\ Fisheries, Brisbane-4001, Australia \\ *Corresponding author \\ e-mail:huma.qureshi@uq.edu.au,humaqureshi8@gmail.com \\ (Received $3^{\text {rd }}$ Mar 2018; accepted $10^{\text {th }}$ May 2018)
}

\begin{abstract}
Phytosociological studies help to understand extent of biological invasion. Multiple analyses of ecological parameters at different locations derive general explanations of impact on species diversity in plant communities. Current study assessed the impact of Parthenium hysterophorus (an annual weed of great significance in Pakistan and worldwide) invasion on native vegetation in Pothwar region of Pakistan. The approach used for the study was random samplings with two categorical factors: invaded and non-invaded under same habitat conditions. Differences in number of species $(\mathrm{S})$, abundance $(\mathrm{N})$, species richness (R), evenness $\left(\mathrm{J}^{\prime}\right)$, Shannon diversity index $\left(\mathrm{H}^{\prime}\right)$ and Simpson index of dominance $(\lambda)$ were compared between invaded and control plots by t-test series. Control plots harbored by average of 0.9 more species per $10 \mathrm{~m}^{2}$. The control category was more diverse $\left(\mathrm{H}^{\prime}=1.73\right)$ than invaded category $\left(\mathrm{H}^{\prime}=1.53\right)$. The higher value of species richness in control plots shows the heterogeneous nature of communities and vice versa in invaded plots. The lower value of index of dominance in invaded plots shows less sample diversity than in the control ones. At multivariate scale, ordination (nMDS) and ANOSIM showed significant magnitude of differences between invaded and control plots in all sites. The most effected site by Parthenium invasion was Jhelum followed by Attock, Rawalpindi, Chakwal and Islamabad. The decrease in diversity indices in invaded over control sites indicated less productive plant communities due to Parthenium invasion. This makes Parthenium a candidate of consideration for appropriate control measures.
\end{abstract}

Keywords: invasion impacts, diversity indices, multivariate analysis, diversity conservation, PRIMER

\section{Introduction}

There has been a rapid acceleration in the number and rate of plant invasions attributed to increased dispersal of exotics and expansion of disturbed habitats associated with rapid human population growth (Collier and Vankat, 2002). The introduction of invasive plants may change the structure and function of ecosystem, e.g., alterations in succession, species composition, biomass, net primary productivity and nutrient cycling (Charles and Dukes, 2007; Dassonville et al., 2008). Invasive species may also deplete available resources. Other studies have shown changes at population, community and landscape levels (Collier and Vankat, 2002; Qureshi et al., 2014). Consequently, studying the community level impacts of the invader identifies its 
potential effects and provides valued information for management and nature conservation strategies (Hejda et al., 2009).

Plant invasions deplete native species diversity, alter community composition and effect ecosystem processes thus cause ecological and economic imbalance (Kunzi et al., 2015). Exotic plants coexist in relative harmony in native habitat but competitively exclude neighbors in recipient communities. Various studies have provided data on the effects of exotic invasive plants on declining indigenous diversity and altering native community composition. These studies assumed different mechanisms that generate substantial invasion impacts. Among these processes are allelopathy, competition, and alteration of native ecosystem characteristics (Odat et al., 2011). Direct competition with native flora may result in monocultures of exotic species, e.g. Parthenium hysterophorus in Pakistan, Australia and India and Psidium cattleianum in Mauritius (Dogra et al., 2010). In different parts of the world, $80 \%$ of endangered species are threatened by alien invasive species (Pimentel et al., 2005).

Parthenium is an aromatic, annual herb native to Mexico, southern United States and South \& Central America. It was inadvertently introduced to many countries and now has become a troublesome rangeland and agricultural weed in parts of Africa, Asia, Australia and the Pacific Islands (Fig. 1). Because of its status in the world, it is documented among world's top ten worst weeds (Tamado and Milberg, 2000; Khan et al., 2014). $P$. hysterophorus is assumed to move in to India along food grains trade in from USA. It then has spread to sub-continent (Nath, 1988). It is supposed to enter Pakistan via road links where automobiles cross at many places every day. In Pakistan, Parthenium weed was stated in the 1980s from Gujarat, Punjab (Razaq et al., 1994). Since then, it has spread rapidly all through to Islamabad, Punjab Province and parts of Khyber Pukhtunkhwa. Parthenium affects biodiversity, crop production and human and animal health (Shabbir, 2013). It grows in a range of habitats. Wide environmental adaptability, drought tolerance, photo and thermo-insensitivity, high seed production, small and light weighted seeds adept of long distance travel via water, wind, birds, animals and vehicles, longevity of seeds in soil seed banks, strong competition and allelopathy contribute to its invasiveness (Khan et al., 2014; Hassan et al., 2012; Shabbir and Bajwa, 2006).

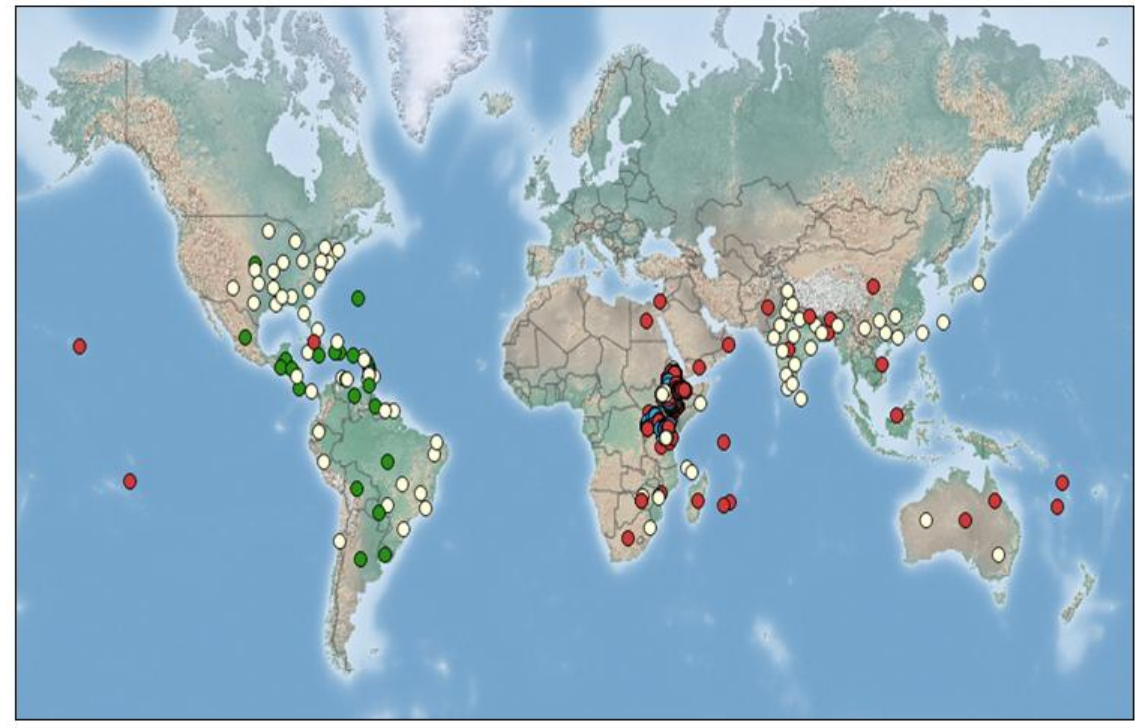

Invasive

- Naturalized

- Not invasive

- Not Recorded

Figure 1. Distribution map and invasion status of Parthenium weed around the globe 
Parthenium is one of the worst weeds presently known in Pakistan. No previous study is reported from Pothwar region regarding its ecological impacts. The current study was carried out to find out (1) what is the effect of Parthenium weed on ecological diversity indices in different districts of Pothwar region (assuming each district as 'site'); (2) do the effects on diversity differ between different sites (districts) in the area?

\section{Materials and methods}

\section{Study area}

Pothwar is a north-eastern plateau in Pakistan, making the northern part of Punjab. It edges Azad Kashmir (the western parts) and Khyber Pakhtunkhwa (southern parts). Pothwar Zone extends from $32.5^{\circ} \mathrm{N}$ to $34.0^{\circ} \mathrm{N}$ latitude and $72^{\circ} \mathrm{E}$ to $74^{\circ} \mathrm{E}$ longitude and lies between the Indus and Jhelum River. The plateau expanses from salt range northward to the foothills of Himalayas. The Pothwar region embraces Jhelum, Islamabad, Attock, Rawalpindi and Chakwal districts (Table 1). Total area of Pothwar region is $28488.9 \mathrm{~km}^{2}$. (Rashid and Rasul, 2011). Pothwar region has an extreme climate with hot summers and cold winters. Weather is divided into four seasons: Cold (December-March); Hot (April-June); Monsoon (July-September) and Post-Monsoon season (October-November). This area gets an average annual rainfall of $812 \mathrm{~mm}$, about half of which occurs in the Monsoon months (July-September). The mean maximum temperature rises till the month of June and then falls appreciably with advent of rains, being coldest in January $\left(14.62-18.7{ }^{\circ} \mathrm{C}\right)$. Average temperatures range from $14{ }^{\circ} \mathrm{C}$ in January to $37{ }^{\circ} \mathrm{C}$ in June (Fig. 2). The region has broadly four types of soil: loess, river alluvium, residual and piedmont alluvium. Due to dynamic climate and combination of hills and plains, Pothwar region is rich in biodiversity. Native vegetation is characterized by open patches of grasses and forb species. Albizia lebbeck (L.) Benth., Acacia modesta Wall., Abies pindrow (Royle ex D. Don) Royle, Cassia fistula L., Cedrela toona Roxb. ex Rottler, Dalbergia sissoo Roxb., Dodonaea viscosa Jacq., Ficus religiosa L., Ficus benghalensis L., Melia azedarach L., Olea cuspidata Wall. Ex G. Don., Zizyphus jujuba Mill. and Zizyphus nummularia (Burm. f.) Wight \& Arn. are principle species in the region (Shabbir et al., 2012; Ghufran et al., 2013).

Table 1. Coordinates of study sites

\begin{tabular}{c|c}
\hline District & Coordinates \\
\hline Jhelum & $32.94^{\circ} \mathrm{N}, 73.72^{\circ} \mathrm{E}$ \\
Islamabad & $33.73^{\circ} \mathrm{N}, 73.09^{\circ} \mathrm{E}$ \\
Attock & $33.76^{\circ} \mathrm{N}, 72.36^{\circ} \mathrm{E}$ \\
Rawalpindi & $33.59^{\circ} \mathrm{N}, 73.04^{\circ} \mathrm{E}$ \\
Chakwal & $32.93^{\circ} \mathrm{N}, 72.85^{\circ} \mathrm{E}$ \\
\hline
\end{tabular}

\section{Experimental design}

Field work was carried out during July-August (being the maximum growth period of plants), 2016. The effect of invasion was studied in each of five districts (Attock, Chakwal, Jhelum, Islamabad and Rawalpindi). Ecological indices for selected invaders 
were calculated and compared at various sites. The sampling technique was random. For each district six invaded and six non-invaded paired vegetation plots (each $3.16 \times 3.16 \mathrm{~m}$ in size, i.e., $10 \mathrm{~m}^{2}$ in area) were sampled. Based on visual observations, plot of invaded vegetation ('invaded plot') where the invader showed dominance was considered as 'treatment' and a second vegetation plot, usually $0.5-1 \mathrm{~km}$ apart from treatment, where invader has no dominance ('non-invaded plot') was considered as the "control". The estimated density of the weed in the area across locations was $4 / \mathrm{m}^{2}$. In all, a total of 60 vegetation plots were sampled (consisting of six paired samples per district, and hence 30 treatments; 30 controls for the entire Pothwar region) (Fig. 3). Within each randomly chosen plot $\left(10 \mathrm{~m}^{2}\right.$ in area), all vascular plant species in control and invaded plots were identified to species level.

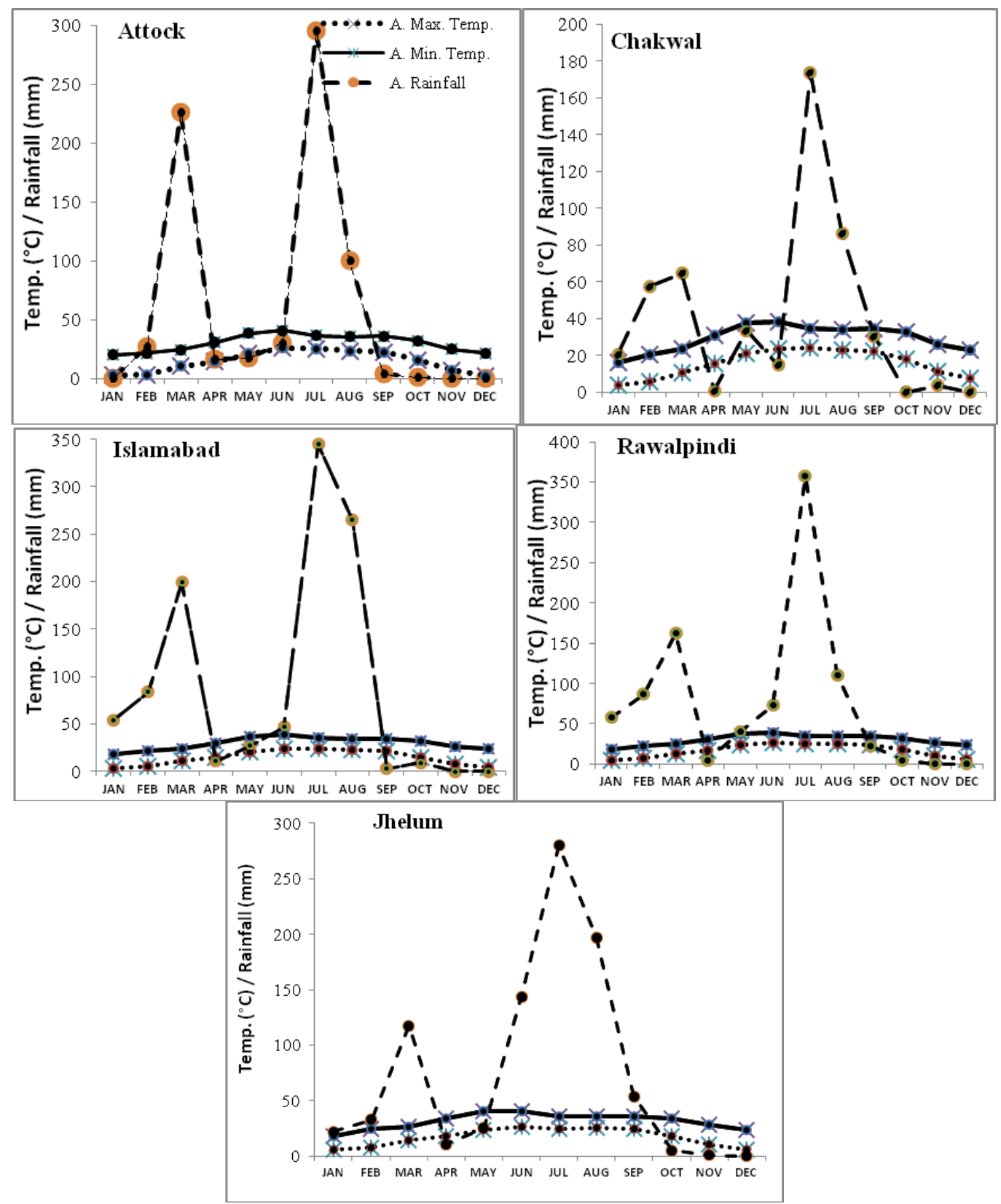

Figure 2. Mean monthly climate data of Pothwar region, Pakistan for year 2017. (Data sourced from Pakistan Meteorological Department University Road Karachi, Pakistan) 


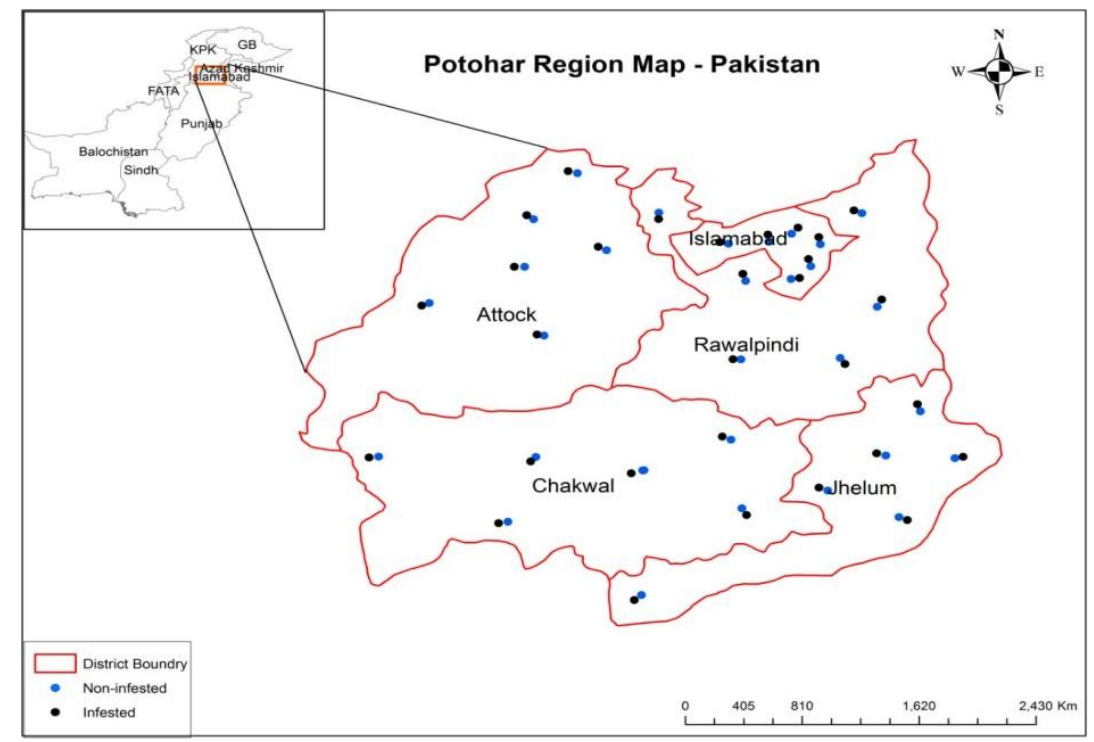

Figure 3. Distribution of plots for impact analysis of Parthenium hysterophorus in Pothwar region

\section{Data analyses}

Species frequency data were created and invasion impacts of $P$. hysterophorus on local flora were assessed by calculating and comparing ecological indices including Margalef's index of richness, Shannon-Weaver index of diversity, Simpson index of dominance and index of evenness for control and invaded sites (Magurran, 1998). These parameters were calculated as (Eqs. 1, 2, 3 and 4):

$$
\text { Margalef }{ }^{\prime} \text { s index of richness }(\mathrm{R})=\frac{\mathrm{s}-1}{\ln \mathrm{N}}
$$

$\mathrm{N}=$ Total number of individuals; $\mathrm{S}=$ Total number of species.

$$
\text { Shannon-Weaver index of diversity }\left(H^{\prime}\right)=-\sum_{i=1}^{S}\left(\frac{n_{i}}{N} \times \ln \frac{n_{i}}{N}\right)
$$

$\mathrm{N}=$ Total number of individuals of all species; $\mathrm{n}=$ Actual number of individuals of one species.

$$
\text { Simpson index of dominance }(\lambda)=1-\frac{\sum_{i=1}^{S} n_{i}\left(n_{i}-1\right)}{N(N-1)}
$$

$\mathrm{N}=$ Total number of individuals of all species; $\mathrm{n}=$ Number of individuals of one species.

$$
\text { Index of evenness }(E)=\frac{H^{\prime}}{\ln S}
$$

$\mathrm{H}^{\prime}$ is Shannon's index; $\mathrm{S}=$ Number of species. 
Rarefaction curves were plotted to determine if sampling was adequate in each district using observed, Coleman's, Jackknife, Bootstrap and Chao 2 models in PRIMER v. 7 (Clarke and Warwick, 2001). All gave comparable results; consequently only that of real (observed) data are presented. Data were then subjected to univariate and multivariate analyses of non-metric multidimensional scaling procedure (Clarke and Gorley, 2015). Data were log transformed to achieve criteria of normality (evenness and Simpson index of diversity). For invasion impact analysis, diversity indices including total number of species $(\mathrm{S})$, abundance $(\mathrm{N})$, species richness $(\mathrm{R})$, species evenness $\left(\mathrm{J}^{\prime}\right)$, Shannon index of diversity $\left(\mathrm{H}^{\prime}\right)$ and Simpson index of dominance $(\lambda)$ were calculated for control as well as for invaded plots. The above ecological indices were subjected to analysis of variance (ANOVA) with invasion status and districts as factors using IBM SPSS v. 21. Differences between ecological indices for five districts were individually tested for significance between invaded and control plots by multiple comparisons tests of t-test. Data were further analyzed for species assemblages by non-metric multidimensional scaling (nMDS) in two-three dimensions with invasion status (control, invaded) as factor using PRIMER V.7 software. nMDS was used to ordinate the similarity of data between site categories (invaded, control) based on Bray-Curtis dissimilarity matrix following log-transformation of species abundance data due to zero species count in some plots. The range of clustering of sites and locations in response to invasion were assessed by analysis of similarity (ANOSIM) and similarity percentage (SIMPER). ANOSIM relates mean difference of ranks between and within groups, generating the Global statistic $(\mathrm{R})$. The values of Global statistic $(\mathrm{R})$ range from -1 to +1 . Values near 0 and negative values demonstrate similarity among groups. Values impending +1 indicate a strong dissimilarity among groups (Clarke and Warwick, 2001; Osunkoya et al., 2017). SIMPER identified species contributed most to average dissimilarity between groups (invaded and control plots). This technique calculates average impact of each species contributing to dissimilarity between groups (Clarke and Warwick, 2001). Values of percentage similarity between groups range between 0 to 100 , with 100 stating maximum similarity.

\section{Results}

To assess sampling completeness, rarefaction curves plotting cumulative number of species as a function of sampling effort were used which indicated that sampling was reasonably complete (Fig. 4). A total of 56 plant species from 50 genera were documented during the study (Table 2). A total of 56 species were recorded in control plots compared with 37 in infested plots. Mean species diversity and richness/quadrat was higher in control plots (Fig. 5).

Table 2. Plant species found in studied plots, family and life form

\begin{tabular}{c|c|c|c}
\hline S\# & Plant species & Family & Life form \\
\hline 1 & Achyranthes aspera $\mathrm{L}$. & Amaranthaceae & Herb \\
2 & Anagallis arvensis $\mathrm{L}$. & Primulaceae & Herb \\
3 & Argemone mexicana $\mathrm{L}$. & Papaveraceae & Herb \\
4 & Amaranthus viridis $\mathrm{L}$. & Amaranthaceae & Herb \\
5 & Astragalus scorplurus Bunge. & Papilionaceae & Herb \\
6 & Bellis perennis $\mathrm{L}$. & Asteraceae & Herb \\
7 & Broussonetia papyrifera (L.) L'Herit. ex Vent. & Moraceae & Tree \\
\hline
\end{tabular}




\begin{tabular}{|c|c|c|c|}
\hline S\# & Plant species & Family & Life form \\
\hline 8 & Calotropis procera $\mathrm{Br}$. & Asclepiadaceae & Shrub \\
\hline 9 & Cannabis sativa $\mathrm{L}$. & Cannabaceae & Herb \\
\hline 10 & Cenchrus biflorus Roxb. & Poaceae & Grass \\
\hline 11 & Chenopodium ambrosioides $\mathrm{L}$. & Chenopodiaceae & Herb \\
\hline 12 & Circium arvense $\mathrm{L}$. & Asteraceae & Herb \\
\hline 13 & Convolvulus arvensis $\mathrm{L}$. & Convolvulaceae & Herb \\
\hline 14 & Cynodon dactylon L. (Pers.) & Poaceae & Grass \\
\hline 15 & Datura alba Nees & Solanaceae & Shrub \\
\hline 16 & Datura innoxia Miller & Solanaceae & Shrub \\
\hline 17 & Dicanthium annulatum Stapf. & Poaceae & Grass \\
\hline 18 & Digitaria ciliaris (Retz.) Koeler & Poaceae & Grass \\
\hline 19 & Erianthus munja $\mathrm{L}$. & Poaceae & Grass \\
\hline 20 & Fumaria indica (Hausskn.) Pugsley & Fumariaceae & Herb \\
\hline 21 & Impatiens edgeworthii Hook. f. & Balsaminaceae & Herb \\
\hline 22 & Lathyrus aphaca L. & Papilionaceae & Herb \\
\hline 23 & Malvestrum coromandelianum (L.) Garcke & Malvaceae & Herb \\
\hline 24 & Medicago polymorpha $\mathrm{L}$. & Papilionaceae & Herb \\
\hline 25 & Роа аппиа $\mathrm{L}$. & Poaceae & Grass \\
\hline 26 & Portulaca oleracea $\mathrm{L}$. & Aizoaceae & Herb \\
\hline 27 & Prosopis cineraria (Linn.) Druce & Mimosaceae & Tree \\
\hline 28 & Prunella vulgaris L. & Labiateae & Herb \\
\hline 29 & Ranunculus muricatus $\mathrm{L}$. & Ranunculaceae & Herb \\
\hline 30 & Ricinus communis L. & Euphorbiaceae & Shrub \\
\hline 31 & Rosa brunonii Lindl. & Rosaceae & Shrub \\
\hline 32 & Rosa damascena Mill. & Rosaceae & Shrub \\
\hline 33 & Rumex hastatus D. Don & Polygonaceae & Shrub \\
\hline 34 & Rumex dentatus $\mathrm{L}$. & Polygonaceae & Herb \\
\hline 35 & Saxifragra androsacea $\mathrm{L}$. & Saxifragaceae & Herb \\
\hline 36 & Silybum marianum (L.) Gaertn. & Asteraceae & Herb \\
\hline 37 & Solanum incanum $\mathrm{L}$. & Solanaceae & Shrub \\
\hline 38 & Solanum miniatum Beruh. ex Willd. & Solanaceae & Herb \\
\hline 39 & Solanum surattense Burm. F. & Solanaceae & Shrub \\
\hline 40 & Solanum nigrum $\mathrm{L}$. & Solanaceae & Herb \\
\hline 41 & Sonchus asper (L.) Hill & Asteraceae & Herb \\
\hline 42 & Sorghum halepense $\mathrm{L}$. & Poaceae & Grass \\
\hline 43 & Suaeda fruticosa Forsk. & Amaranthaceae & Shrub \\
\hline 44 & Swertia paniculata Wall. & Gentianaceae & Herb \\
\hline 45 & Taraxacum officinale (L.) Weber ex F.H. Wigg & Asteraceae & Herb \\
\hline 46 & Tamarix aphylla (L.) Karst. & Tamaricaceae & Tree \\
\hline 47 & Tephrosia purpurea (Linn.) Pers. & Papilionaceae & Herb \\
\hline 48 & Tinospora cordifolia Miers ex Hook. $\mathrm{f}$ & Menispermaceae & Herb \\
\hline 49 & Tribulus terrestris $\mathrm{L}$. & Zygophyllaceae & Herb \\
\hline 50 & Urtica dioica $\mathrm{L}$. & Urticaceae & Herb \\
\hline 51 & Withania somnifera L. (Dunal) & Solanaceae & Shrub \\
\hline 52 & Zizyphus mauritiana Lamk. & Rhamnaceae & Shrub \\
\hline 53 & Capsella bursa-pestoris (L.) Medik. & Brassicaceae & Herb \\
\hline 54 & Cyperus rotundus $\mathrm{L}$. & Cyperaceae & Sedge \\
\hline 55 & Polygonum plabegem $\mathrm{R}$. Br. & Polygonaceae & Herb \\
\hline 56 & Eclipta prostata $\mathrm{L}$. & Asteraceae & Herb \\
\hline
\end{tabular}




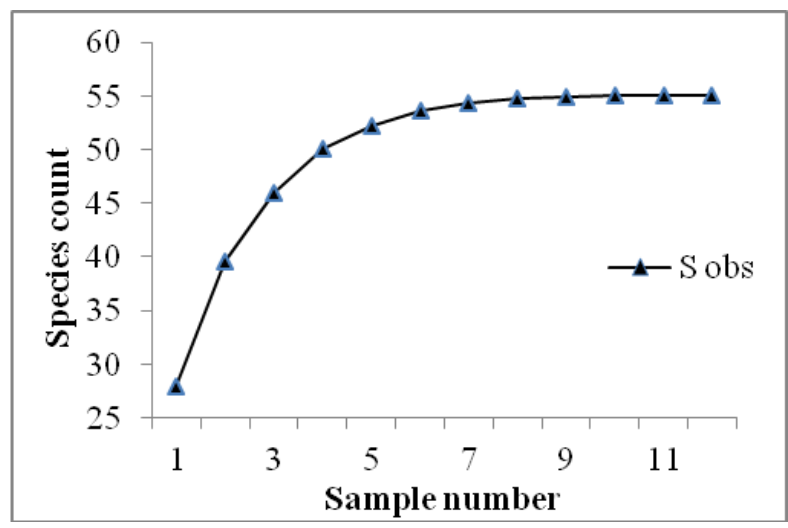

Figure 4. Rarefaction curve showing cumulative number of species recorded as a function of sampling effort
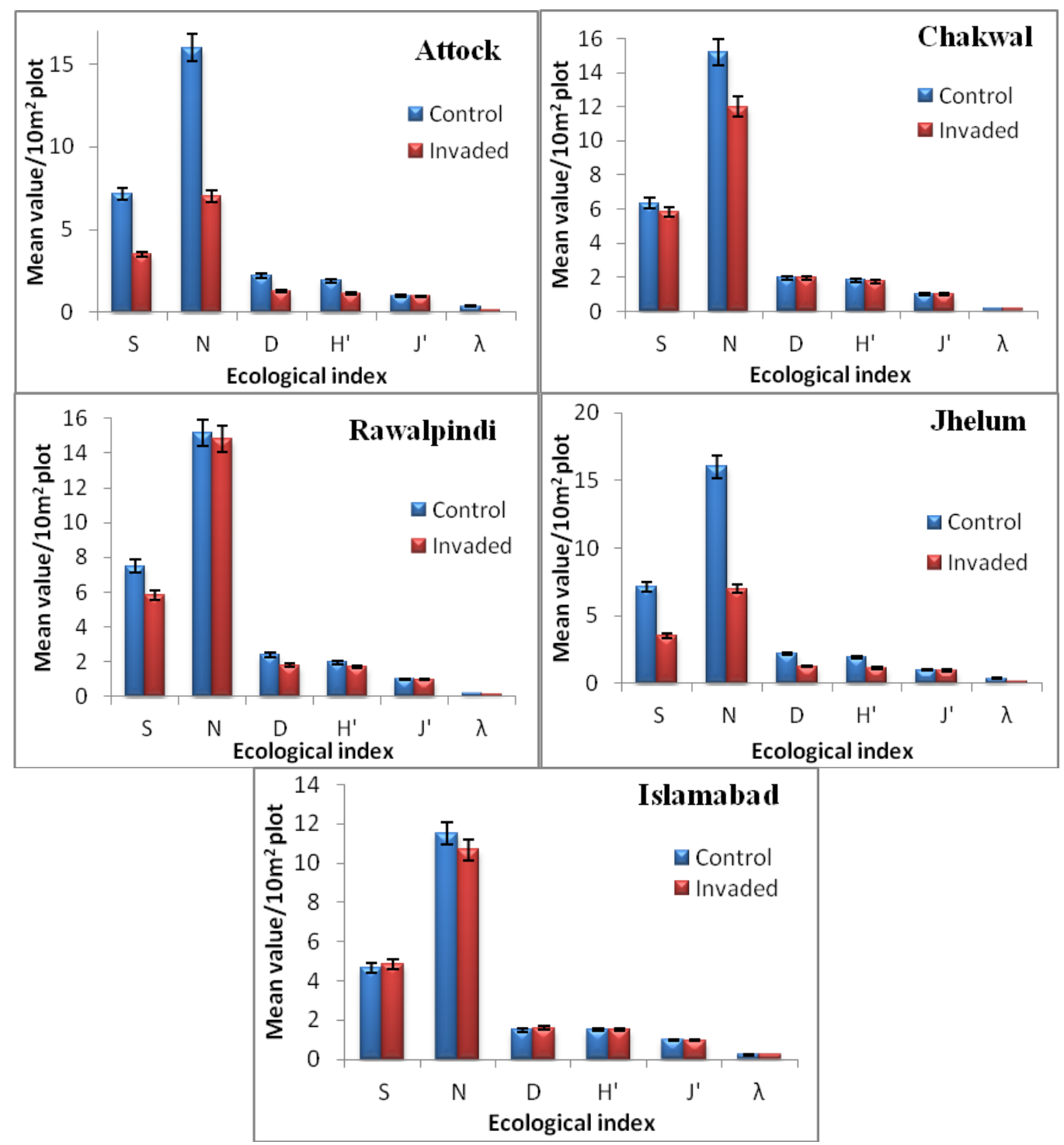

Figure 5. Mean values $/ 10 \mathrm{~m}^{2}$ for ecological indices of invaded vs control plots in different sites. ( $S=$ Number of species; $N=$ Abundance; $D=$ Species richness; $H^{\prime}=$ Shannon index of diversity; $J^{\prime}=$ Species evenness; $\lambda=$ Simpson index of dominance) 
Comparisons of ecological indices showed significant difference across districts and invasion status. Parthenium invasion exhibited variable impact across five districts by reducing species number per plot $(\mathrm{S})$ and abundance $(\mathrm{N})$ up to a maximum of $40 \%$ in Attock. Control plots harbored on average $6.033 \pm 1.75($ mean $\pm \mathrm{SD}, \mathrm{n}=30$ ) species. This was greater than that observed in the invaded plots $(5.133 \pm 1.83)$ and the difference was statistically significant $(\mathrm{t}=2.09, \mathrm{df}=29, \mathrm{p}=0.045)$. A total of 181 and 154 individuals were recorded in control and invaded plots respectively. Similarly, abundance in control and invaded plots differed by $3.7 \pm 3.83$ (mean $\pm \mathrm{SD}, \mathrm{n}=30)$ and the difference was significant $(\mathrm{t}=4.34, \mathrm{df}=29, \mathrm{p}<0.0001)$. Control plots also exhibited higher values of species richness by a difference of $0.15 \pm 0.51$, species evenness by $0.019 \pm 0.02$; Shannon index of diversity by $0.2 \pm 0.34$ and Simpson index of dominance by $0.22 \pm 0.35$ (Table 3).

Table 3. Analysis of variance (ANOVA) of invasion impacts and district on diversity indices of local plant community

\begin{tabular}{c|c|c|c|c|c}
\hline \multirow{2}{*}{ Ecological index } & \multicolumn{3}{|c|}{ SUMMARY ANOVA } & \multicolumn{2}{c}{ Mean ( \pm SD) } \\
\cline { 2 - 6 } & District (D) & $\begin{array}{c}\text { Invasion } \\
\text { status (IS) }\end{array}$ & $\begin{array}{c}\text { D IS } \\
\text { interaction }\end{array}$ & Control (30) & Invaded (30) \\
\hline No. of species $(\mathrm{S}) / 10 \mathrm{~m}^{2}$ & $* *$ & $* *$ & $* * *$ & $6.033 \pm 1.75$ & $5.133 \pm 1.83$ \\
Abundance $(\mathrm{N}) / 10 \mathrm{~m}^{2}$ & $* *$ & $* * *$ & $* *$ & $14.4 \pm 3.81$ & $10.70 \pm 3.86$ \\
Species richness (R) & $* *$ & $\mathrm{NS}$ & $* * *$ & $1.87 \pm 0.49$ & $1.62 \pm 0.53$ \\
Species evenness $\left(\mathrm{J}^{\prime}\right)$ & $\mathrm{NS}$ & $* *$ & $\mathrm{NS}$ & $0.028 \pm 0.039$ & $0.009 \pm 0.006$ \\
Shannon index of diversity $\left(\mathrm{H}^{\prime}\right)$ & $* *$ & $* *$ & $* * *$ & $1.73 \pm 0.29$ & $1.53 \pm 0.406$ \\
Simpson index of dominance $(\lambda)$ & $* *$ & $* *$ & $* * *$ & $1.72 \pm 0.29$ & $1.50 \pm 0.42$ \\
\hline
\end{tabular}

$* * * \mathrm{P} \leq 0.001 ; * * \mathrm{P} \leq 0.02 ; * \mathrm{P} \leq 0.05 ; \mathrm{NS}$ (not significant) $\mathrm{P}>0.05$

For individual district, native flora differed significantly in species density $(\mathrm{S})$, abundance per plot $(\mathrm{N})$, species evenness $\left(\mathrm{J}^{\prime}\right)$ and Simpson index of dominance $(\lambda)$ but not in overall species richness (R) and Shannon index of diversity $\left(\mathrm{H}^{\prime}\right)$. Parthenium invasion had significant impacts on all ecological indices except species richness $(\mathrm{R})$ at site 1 (Attock). For site 2 (Chakwal), only abundance was affected significantly. For site 3 (Islamabad) invasion impacts were not significant only on native species abundance. Species evenness $\left(\mathrm{J}^{\prime}\right)$ was non-significant for site 4 (Jhelum) while for site 5 (Rawalpindi) the only index significantly affected by Parthenium invasion was species evenness (J') (Table 4).

Table 4. Student's t-test for significance of differences between control and invaded plots at different sites

\begin{tabular}{c|c|c|c|c|c|c}
\hline Site & $\begin{array}{c}\text { Number of } \\
\text { species (S) }\end{array}$ & $\begin{array}{c}\text { Abundance } \\
(\mathbf{N})\end{array}$ & $\begin{array}{c}\text { Species } \\
\text { richness (D) }\end{array}$ & $\begin{array}{c}\text { Species } \\
\text { evenness (J') }\end{array}$ & $\begin{array}{c}\text { Shannon index } \\
\text { of diversity (H') }\end{array}$ & $\begin{array}{c}\text { Simpson index } \\
\text { of dominance }(\boldsymbol{\lambda})\end{array}$ \\
\hline Attock & $*$ & $* *$ & NS & $*$ & $* *$ & $*$ \\
Chakwal & NS & $*$ & NS & NS & NS & NS \\
Rawalpindi & $* *$ & NS & $* *$ & $* *$ & $* *$ & $* *$ \\
Jhelum & $* * *$ & $* *$ & $* *$ & NS & $* *$ & $* *$ \\
Islamabad & NS & NS & NS & $* * *$ & NS & NS \\
\hline
\end{tabular}

$* * * \mathrm{P} \leq 0.001 ; * * \mathrm{P} \leq 0.02 ; * \mathrm{P} \leq 0.05 ; \mathrm{NS}$ (not significant) $\mathrm{P}>0.05$ 
The ordination (nMDS) and ANOSIM showed significant magnitude of differences between species composition of invaded and control plots in all sites with global $\mathrm{R}$ values of $0.876(p=0.002), 0.519(p=0.002), 0.598(p=0.002), 0.907(p=0.002)$ and 0.759 ( $\mathrm{p}=0.002)$ for Attock, Chakwal, Islamabad, Jhelum and Rawalpindi, respectively (Fig. 6). The greatest dissimilarity between invaded and control plots was noticed by Jhelum.

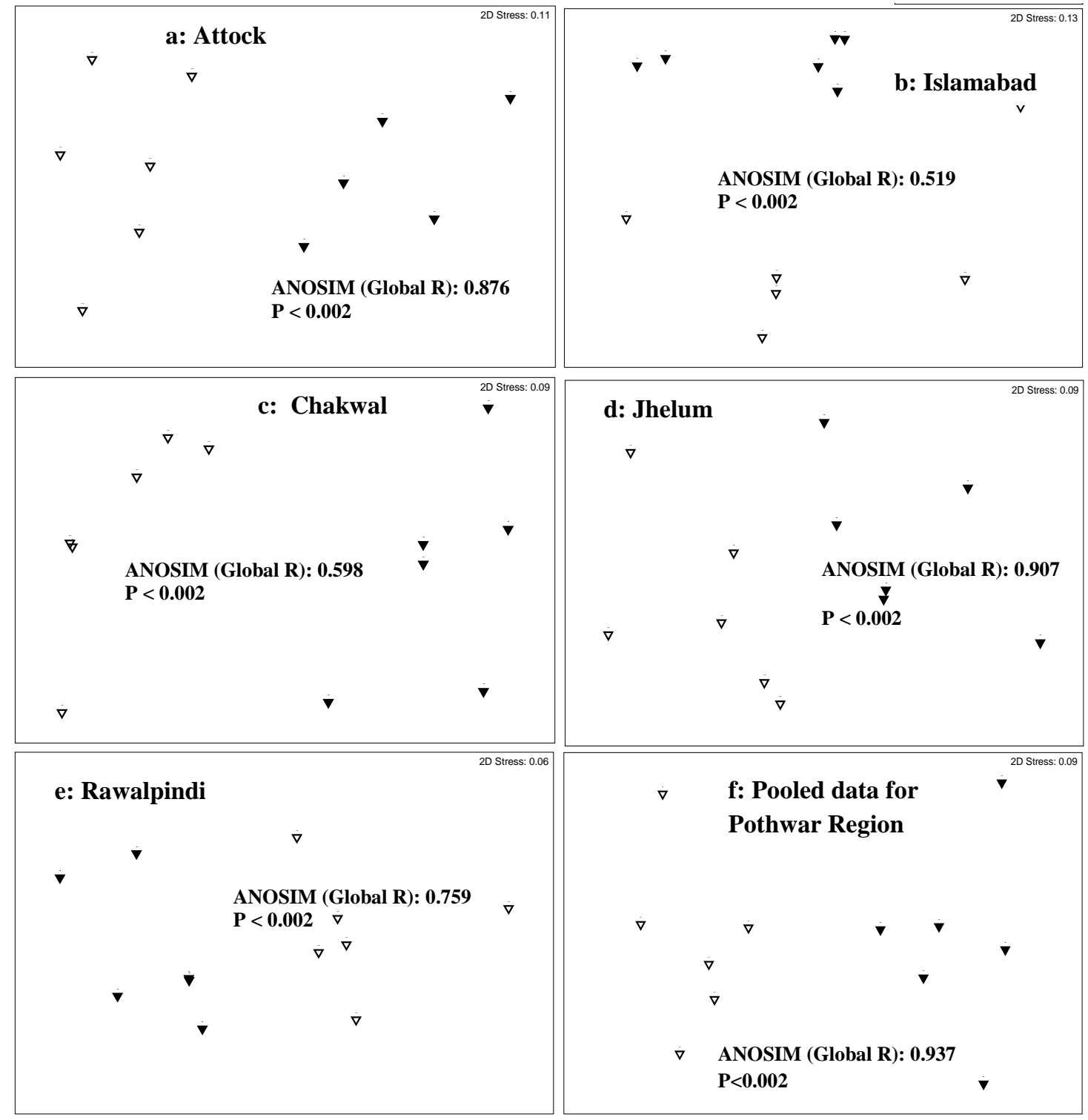

Figure 6. Multidimensional scaling (MDS) ordination and analyses of similarity (ANOSIM) results of invasion status data for Pothwar region, Pakistan (open symbols are for control, uninvaded plots, and closed symbols are for invaded plots)

Similarity percentage (SIMPER) analysis of data suggested those species contributing most to average dissimilarity between control and invaded groups. This analysis also computed average contribution of species causing dissimilarity. Few top species separating invaded plots from non-invaded plots (control) for analysis are enlisted in Table 5. Tephrosia purpurea and Lathyrus aphaca were found in control 
plots while they were not observed in invaded plots, whereas a grass species (Poa апnиа), and broad leaf species like Solanum, Ricinus and Taraxacum were conspicuously displaced in Parthenium invaded plots.

Table 5. SIPMER analysis of Parthenium invaded and control sites in Pothwar region, Pakistan. Data have been pooled prior to analyses across districts

\begin{tabular}{c|c|c|c|c|c}
\hline \multicolumn{5}{c}{$\begin{array}{c}\text { Average dissimilarity } \\
\text { Average abundance }\end{array}$} \\
Species & Control & Invaded & Av. Diss. & Diss./SD & $\begin{array}{c}\text { Contribution } \\
(\%)\end{array}$ \\
\hline Poa annua L. & 2.94 & 0.00 & 2.38 & 8.06 & 3.95 \\
Lathyrus aphaca L. & 0.00 & 2.69 & 2.18 & 5.82 & 3.63 \\
Solanum miniatum L. & 2.47 & 0.00 & 2.00 & 7.85 & 3.32 \\
Ricinus communis L. & 2.19 & 0.00 & 1.77 & 2.05 & 2.95 \\
Convolvulus arvensis L. & 1.80 & 1.79 & 1.49 & 1.32 & 2.48 \\
Taraxacum officinale (L.) Weber ex F.H. Wigg & 1.77 & 0.00 & 1.40 & 2.07 & 2.32 \\
Rosa damascena Mill. & 1.82 & 0.18 & 1.38 & 1.41 & 2.29 \\
Tribulus terrestris L. & 1.62 & 0.00 & 1.31 & 2.03 & 2.18 \\
Fumaria indica (Hausskn.) Pugsley & 2.35 & 1.15 & 1.31 & 1.55 & 2.18 \\
Tephrosia purpurea (L.) Pers. & 0.00 & 1.63 & 1.29 & 1.36 & 2.15 \\
Portulaca oleracea L. & 1.94 & 1.10 & 1.26 & 2.37 & 2.10 \\
Circium arvense L. & 1.63 & 0.00 & 1.25 & 1.69 & 2.08 \\
Saxifragara sndrosacea L. & 1.73 & 0.54 & 1.24 & 1.51 & 2.06 \\
Anagallis arvensis L. & 2.67 & 1.49 & 1.24 & 1.24 & 2.06 \\
Tinospora cordifolia Miers ex Hook. f. & 1.52 & 0.00 & 1.23 & 1.90 & 2.04 \\
Solanum nigrum L. & 1.87 & 0.86 & 1.21 & 1.92 & 2.02 \\
Saxifragra androsacea L. & 1.51 & 0.00 & 1.19 & 1.34 & 1.97 \\
Tamarix aphylla (L.) Karst. & 1.39 & 0.40 & 1.15 & 0.96 & 1.91 \\
Solanum incanum L. & 1.74 & 1.04 & 1.12 & 1.56 & 1.87 \\
Eclipta prostata L. & 1.95 & 1.02 & 1.12 & 1.25 & 1.86 \\
\hline
\end{tabular}

Values are average abundance ranking (1-rare; 2-common; 3-very common; >4-dominant)

\section{Discussion}

Parthenium weed exerts significant impact on natural communities by displacement of native species and hence exert discrepancy in natural ecosystems. This discrepancy results in formation of its large monocultures. In present study, comparisons of ecological indices across invaded and control plots indicated significant differences in the study area. These findings are in-line with other studies on this alien invasive weed, in which indicated strong effects of the invader on ecosystem properties, e.g., in grazing and wastelands of district Attock (Riaz and Javaid, 2011), district Hafizabad, (Riaz and Javaid, 2010) and Islamabad, Pakistan (Shabbir and Bajwa, 2007).

The results show modifications in vegetation composition of invaded and control plots. Analysis of variance among invaded and control plots showed significant decrease in ecological indices across site and invasion status. These results are consistent with other studies on invasive species indicating their negative effects on biodiversity and ecosystem properties (Manchester, 2000; McNeely, 2001; Grice, 2006; 
Borokini et al., 2011; Jeschke et al., 2014; Panetta and Gooden, 2017). In our study, despite the negative effect of $P$. hysterophorus on species composition, species evenness of control and invaded plots was not significantly different. That is contradiction to above-mentioned studies; however, a few studies have shown that invasive species pose little or no effect on species diversity (e.g., Martin, 1999; Hejda and Pysek, 2006; Timsina et al., 2011). It is reported elsewhere that Parthenium invasion enriches compositional diversity but may result in extinction of native species (Nigatu and Sharma, 2013).

Wide environmental adaptability, drought tolerance, photo and thermo-insensitivity, high seed production and short life cycle (being an annual), small and light seeds capable of long distance travel via water, wind, birds, animals and vehicles, longevity of seeds in soil seed banks, strong competition and allelopathy contribute to the invasiveness of Parthenium weed (Shabbir and Bajwa, 2006; Hassan et al., 2012; Khan et al., 2014). Allelopathy especially plays important role in the invasion of this weed. The major allelopathic compounds found in P. hysterophorus are, gentisic, o-coumaric, p-coumaric, ferulic, vallinic, caffeic, salicylic acid, p-hydroxybenzoic and transcinammic acids and sesquiterpene lactone etc. (Borah et al., 2016). These allelochemicals are supposed to reduce native seed germination, allowing the weed to pre-empt space and establish monocultures.

Parthenium invasion exhibited variable impacts in five sites by reducing species number per plot $(S)$, abundance $(N)$, species richness $(R)$, species evenness $\left(J^{\prime}\right)$, Simpson index of dominance $(\lambda)$ and Shannon index of diversity $\left(H^{\prime}\right)$. The trend of decrease in ecological indices in invaded plots is similar to invasion studies on $P$. hysterophorus from Australia, Ethiopia, Nigeria, Tanzania and India (Grice, 2006; Kilewa and Rashid, 2012; Seta et al., 2013; Borokini et al., 2011; Abdulkerim-Ute and Legesse, 2016). The most effected site by Parthenium invasion was Jhelum followed by Attock, Rawalpindi, Chakwal and Islamabad. The lowest invasion impacts in Islamabad compared to other sites are probably because of management practices in the area being its importance as metropolitan region of Pakistan while highest dissimilarity in invaded and control plots in Jhelum is possibly due to the saline soil of the area (Anonymous, 2017).

The ordination (nMDS) and ANOSIM showed significant magnitude of differences between species assemblages of invaded and control plots. The difference was significant for all of five study sites but the greatest dissimilarity between invaded and control plots were noticed by Jhelum. It was reported that the Parthenium plant has a higher survival rate in higher level of soil salinity (Upadhyay et al., 2013), a condition inimical to establishment of many native plant species. Consequently the higher invasion impacts in Jhelum are possibly due to its saline soil (Anonymous, 2017).

SIMPER analysis showed dominance of fewer species in invaded plots than in control. These were Tephrosia purpurea and Lathyrus aphaca. Possible reason for their presence in invaded plot may be due to their aggressive nature as weeds in their own right. Perhaps higher contribution values of Fabaceae weeds is due to competition potential with Parthenium as suggested by Belachew and Tessema (2015); Gnanavel (2013). There is an urgent need of appropriate control measures including the use of proven biological control agents for this weed in Pakistan as done elsewhere around the globe/world, e.g., Australia and South Africa (Kaur et al., 2014; Strathie et al., 2011). 


\section{Conclusion}

The increased occurrence of invasion around the world poses a major threat to indigenous diversity. Plant invasions in novel areas deplete species diversity, alter indigenous community composition, affect ecosystem processes and thus cause huge ecological and economic imbalance. Invasive species studied in the past revealed that the effects of invasion are complex and can permanently alter the function and structure of communities, cause local annihilations and changes in ecosystem processes. Invasion by alien plant species affect the composition and dynamics of species on a wide scale and have great impact on ecosystem functions. The decrease in ecological diversity indices in invaded over control sites in present study indicated that plant communities become less productive due to Parthenium invasion, hence it is a threat to plant diversity of invaded areas. There is an urgent need of appropriate control measures including the use of proven biological control agents for this weed in Pakistan.

Acknowledgements. Pakistan Meteorological Department University Road Karachi, Pakistan is acknowledged for providing climate data of Pothwar region, Pakistan.

\section{REFERENCES}

[1] Abdulkerim-Ute, J., Legesse, B. (2016): Parthenium hysterophorus L: Distribution, impact, and possible mitigation measures in Ethiopia. - Tropical and Subtropical Agroecosystems 19: 61-72.

[2] Anonymous (2017): https://en.wikipedia.org/wiki/Jhelum_District.

[3] Belachew, K., Tessema, T. (2015): Assessment of weed flora composition in Parthenium (Parthenium hysterophorus L.) infested area of East Shewa Zone, Ethiopia. - Malaysian Journal of Medical and Biological Research 2(1): 63-70.

[4] Borah, N., Rabha, D., Athokpam, F. D. (2016): Tree species diversity in tropical forests of Barak valley in Assam, India. - Tropical Plant Research 3(1): 01-09.

[5] Borokini, T. I. (2011): Invasive alien plant species in Nigeria and their effects on biodiversity conservation. - Tropical Conservation Science 4(1): 103-110.

[6] Charles, H., Dukes, J. S. (2007): 13 Impacts of Invasive Species on Ecosystem Services. - Ecological Studies, Ecological Studies 193: 217-237.

[7] Clarke, K. R., Gorley, R. N. (2015): PRIMER V7: user manual/tutorial. - Plymouth Marine Laboratory, Plymouth.

[8] Clarke, K. R., Warwick, R. M. (2001): Change in marine communities: an approach to statistical analyses and interpretation, 2nd ed. - PRIMER-E, Plymouth.

[9] Collier, M. H., Vankat, J. L. (2002): Diminished plant richness and abundance below Lonicera maackii, an invasive shrub. - The American Midland Naturalist 147: 60-71.

[10] Dassonville, N., Vanderhoeven, S., Vanparys, V., Hayez, M., Gruber, W., Meerts, P. (2008): Impacts of alien invasive plants on soil nutrients are correlated with initial site conditions in NW Europe. - Oecologia 157: 131-140.

[11] Dogra, K. S., Sood, S. K., Dobhal, P. K., Sharma, S. (2010): Alien plant invasion and their impact on indigenous species diversity at global scale: A review. - Journal of Ecology and the Natural Environment 2: 175-186.

[12] Ghufran, M. A., Hamid, N., Ali, A., Ali, S. M. (2013): Prevalence of allergenic pollen grains in the city of Islamabad, Pakistan and its impact on human health. - Pakistan Journal of Botany 45: 1387-1390.

[13] Gnanavel, I. (2013): Parthenium hysterophorus L.: A major threat to natural and agro eco-systems in India. - Science International 1(5): 124-131. 
[14] Grice, A. C. (2006): The impacts of invasive plant species on the biodiversity of Australian rangelands. - The Rangeland Journal 28: 27-35.

[15] Hassan, G., Marwat, K. B., Ali, S., Munir, M., Khaliq, P. (2012): Parthenium hysterophorus L. - A predominant weed flora among phytosociology of Islamabad, Pakistan. - Pakistan Journal of Weed Science Research 18: 149-156.

[16] Hejda, M., Pysek, P. (2006): What is the impact of Impatiens glandulifera on species diversity of invaded riparian vegetation? - Biological Conservation 132: 143-152.

[17] Hejda, M., Pysek, P., Jarosik, V. (2009): Impact of invasive plants on the species richness, diversity and composition of invaded communities. - Journal of Ecology 97: 393-403.

[18] Jeschke, J. M., Bacher, S., Blackburn, T. M., Dick, J. T. A., Essl, F., Evans, T., Gaertner, M., Hulme, P. E., Kuhn, I., Mrugala, A., Pergl, J., Pysek, P., Rabitsch, W., Ricciardi, A., Richardson, D. M., Sendek, A., Vila, M., Winter, M., Kumschick, S. (2014): Defining the impact of non-native species. - Conservation Biology 28(5): 1188-1194.

[19] Kaur, M., Aggarwal, N. K., Kumar, V., Dhiman, R. (2014): Effects and management of Parthenium hysterophorus: A weed of global significance. - International Scholarly Research Notices. http://dx.doi.org/10.1155/2014/368647.

[20] Khan, H., Marwat, K. B., Hassan, G., Khan, M. A., Hashim, S. (2014): Distribution of Parthenium weed in Peshawar valley, Khyber Pakhtunkhwa-Pakistan. - Pakistan Journal of Botany 46: 81-90.

[21] Kilewa, R., Rashid, A. (2012): Distribution of invasive weed Parthenium hysterophorus in natural and Agro-Ecosystems in Arusha Tanzania. - International Journal of Science and Research 3(12): 1724-1727.

[22] Kunzi, Y., Prati, D., Fischer, M., Bloch, S. (2015): Reduction of native diversity by invasive plants depends on habitat conditions. - American Journal of Plant Sciences 6: 2718-2733.

[23] Manchester, J. S., Bullock, J. M. (2000): The impacts of non-native species on UK biodiversity and the effectiveness of control. - Journal of Applied Ecology 37: 845-864.

[24] Magurran, A. E. (1988): Ecological diversity and its measurement. - Princeton University Press, Princeton, NJ.

[25] Martin, P. H. (1999): Norway maple Acer platanoides invasion of a natural forest stand, understory consequence and regeneration pattern. - Biological Invasions 1: 215-222.

[26] McNeely, J. (2001): Invasive species: a costly catastrophe for native biodiversity. - Land Use and Water Resources Research 2: 1-10.

[27] Nath, R. (1988): Parthenium hysterophorus L. A review. - Agricultural Reviews 9: 171179.

[28] Nigatu, L., Sharma, J. J. (2013): Parthenium weed invasion and biodiversity loss in Ethiopia: A literature review. - African Crop Science Conference Proceedings 11: 377381.

[29] Odat, N., Al-Khateeb, W., Muhaidat, R., Al U'datt, M., Irshiad, L. (2011): The effect of exotic Acacia saligna tree on plant biodiversity of Northern Jordan. - International Journal of Agriculture and Biology 13: 823-826.

[30] Osunkoya, O. O., Akinsanmi, O. A., Lim, L. S. A., Perrett, C., Callander, J., Dhileepan, K. (2017): Parthenium hysterophorus L. (Asteraceae) invasion had limited impact on major soil nutrients and enzyme activity: Is the null effect real or reflects data insensitivity? - Plant Soil. https://doi.org/10.1007/s11104-017-3375-x.

[31] Panetta, F. D., Gooden, B. (2017): Managing for biodiversity: impact and action thresholds for invasive plants in natural ecosystems. - NeoBiota 34: 53-66.

[32] Pimente, L. D., Zuniga, R., Morrison, D. (2005): Update on the environmental and economic costs associated with alien-invasive species in the United States. - Ecological Economics 52: 273- 288.

[33] Qureshi, H., Arshad, M., Bibi, Y. (2014): Invasive flora of Pakistan: A critical analysis. International Journal of Biosciences 4: 407-424. 
[34] Rashid, K., Rasul, G. (2011): Rainfall variability and Maize production over the Potohar Plateau of Pakistan. - Pakistan Journal of Meteorology 8: 63-74.

[35] Razaq, Z. A., Vahidy, A. A., Ali, S. I. (1994): Chromosome numbers in Compositae from Pakistan. - Annals of the Missouri Botanical Garden 81: 800-808.

[36] Riaz, T., Javaid, A. (2010): Prevalence of invasive Parthenium weed in District Hafizabad, Pakistan. - The Journal of Animal and Plant Sciences 20(2): 90-93.

[37] Riaz, T., Javaid, A. (2011): Prevalence of alien weed Parthenium hysterophorus L. in grazing and wastelands of district Attock, Pakistan. - The Journal of Animal and Plant Sciences 21(3): 542-545.

[38] Seta, T., Assefa, A., Mesfin, F., Balcha, A. (2013): Distribution status and the impact of Parthenium weed (Parthenium hysterophorus L.) at Gedeo Zone (Southern Ethiopia). African Journal of Agricultural Research 8(4): 386-397.

[39] Shabbir, A. (2013): Parthenium invasion in Rawalpindi, Pakistan. - Indian Journal of Weed Science 45: 263-266.

[40] Shabbir, A., Bajwa, R. (2006): Distribution of Parthenium weed (Parthenium hysterophorus L.): An alien invasive weed species threatening the biodiversity of Islamabad. - Weed Biology and Management 6: 89-95.

[41] Shabbir, A., Bajwa, R. (2007): Parthenium invasion in Pakistan. A threat still unrecognized. - Pakistan Journal of Botany 39(7): 2519-2526.

[42] Shabbir, A., Dhileepan, K., Adkins, S. W. (2012): Spread of Parthenium weed and its biological control agent in the Punjab, Pakistan. - Pakistan Journal of Weed Science Research 18: 581-588.

[43] Strathie, L. W., McConnachie, A. J., Retief, E. (2011): Initiation of biological control against Parthenium hysterophorus L. (Asteraceae) in South Africa. - African Entomology 19(2): 378-392.

[44] Tamado, T., Milberg, P. (2000): Weed flora in arable fields of eastern Ethiopia with emphasis on the occurrence of Parthenium hysterophorus. - Weed Research 40: 507-521.

[45] Timsina, B., Shrestha, B. B., Rokaya, M. B., Münzbergová, Z. (2011): Impact of Parthenium hysterophorus L. invasion on plant species composition and soil properties of grassland communities in Nepal. - Flora 206(3): 233-240.

[46] Upadhyay, S. K., Ahmad, M., Singh, A. (2013): Ecological impacts of weed (Parthenium hysterophorus L.) invasion in saline soil. - International Journal of Scientific and Research Publications 3(4): 1-4. 